\title{
Pengaruh Profitabilitas, Likuiditas, Ukuran Perusahaan terhadap Struktur Modal Perusahaan Property dan Real Estate yang terdaftar di BEI
}

\author{
Wirda Lilia \\ Universitas Prima Indonesia \\ liliawirda@ymail.com \\ Verawaty \\ Univesitas Prima Indonesia \\ Verachung10@gmail.com
}

\author{
Sari Indah Lestari Situmeang \\ Universitas Prima Indonesia \\ sari.indahlestari17@gmail.com \\ Davin Hartanto \\ Universitas Prima Indonesia \\ davinhartanto@gmail.com
}

Corresponding Author : Sari Indah Lestari Situmeang

Submitted: 27 Juni 2020

Accepted: 27 Agustus 2020

Published: 27 Agustus 2020

Meningkatnya permintaan terhadap tanah dan bangunan mengakibatkan melonjaknya pembangunan pada sektor property dan real estate. Namun yang harus diketahui adalah bagaimana suatu perusahaan mengelolah struktur modalnya. Struktur modal yang baik pasti akan memiliki dampak yang baik bagi nilai atau finansial sebuah perusahaan yang tinggi. Penelitian ini bertujuan untuk mengetahui pengaruh profitabilitas, likuiditas, ukuran perusahaan terhadap struktur modal pada perusahaan property dan real estate.Populasi yang terdapat dalam penelitian ini sebanyak 61 perusahaan. Sampel dari penelitian ini adalah 28 perusahaan yang diseleksi dengan menggunakan teknik purposive sampling sehingga didapatkan total sampel selama 4 tahun 112 sampel penelitian. Metode penelitian menggunakan Teknik Analisis dengan uji asumsi klasik. Berdasarkan hasil penelitian dari Uji F diperoleh bahwa Profitabilitas, Likuiditas, Ukuran Perusahaan secara bersama-sama berpengaruh dan signifikan terhadap Struktur Modal.Pada Uji t variabel Profitabilitas dan variabel Likuiditas berpengaruh negatif dan tidak signifikan terhadap Struktur Modal.Ukuran Perusahaan berpengaruh positif dan signifikan terhadap Struktur Modal pada perusahaan Property dan Real Estate pada perusahaan property dan real estate. Berdasarkan hasil penelitian membuktikan besar nilai Adjusted $\mathrm{R}$ Square $\left(\mathrm{R}^{2}\right)$ sejumlah 0,292 atau sama dengan $29,2 \%$ dapat berpengaruh dari variabel independen sedangkan selebihnya yaitu 0,64110 atau sama dengan $64,1 \%$ dipengaruhi variabel diluar penelitian.

Kata kunci : Profitabilitas, Likuiditas, Ukuran Perusahaan, struktur Modal

\section{PENDAHULUAN}

\subsection{Latar Belakang}

Keberadaan

dibidang industri property dan real estate mempunyai faktor yang sangat penting bagi bisnis khususnya dalam bidang perekonomian.Tujuan sebuah perusahaan adalah untuk meningkatkan laba perusahaan agar para investor tetap berinvestasi. Perusahaan memerlukan 
faktor-faktor penting agar dapat menunjang produktifitas yang baik dalam kegiatanpemasaran ataupun dalam membuat strategi. Struktur modal merupakan pembelanjaan permanen dari perusahaan yang mencerminkan perbandingan antara hutang jangka panjang perusahaan dengan modal sendiri yang berupa laba ditahan dan penerbitan saham (Deviani \& Sudjarni, 2018). Struktur modal yang baik pasti akan memiliki dampak yang baik bagi nilai atau finansial sebuah perusahaan yang tinggi. Jika ada kesalahan dalam mengelolah struktur modal dapat mengakibatkan hutang perusahaan yang besar dan membuat perusahaan tidak akan sanggup membayar hutang-hutang perusahaan. Masalah struktur modal merupakan masalah yang sangat penting bagi setiap perusahaan, struktur modal akan mempunyai dampak terhadap keuangan perusahaan. Kesalahan menentukan struktur modal akan berpengaruh terhadap keberlangsungan suatu perusahaan, terutama jika hutang perusahaan besar, maka beban yang akan di tanggung semakin besar juga (Maryanti, 2016)

Belakangan ini bisnis dibidang property dan real estate sangat diminati para pembisnis besar. Dapat dikatakan ketika bisnis properti mengalami keuntungan yang pesat maka para investor akan mudah untuk berinvestasi (Kusna \& Setijani, 2018). Profitabilitas adalah rasio yang digunakan untuk mengukur kemampuan perusahaan untuk memperoleh laba dalam waktu tertentu. Profitabilitas yang besar akan menarik para investor untuk menanamkan dananya dikarenakan investor beranggapan akan return yang akan diterima juga besar. Menurut (Eviani, 2015), pecking order therory menyatakan bahwa, perusahaan yang profitnya tinggi maka justru mempunyai hutang yang rendah, itu disebabkan perusahaan tersebut memiliki sumber dana internal. Rasio profitabilitas dapat diwakili oleh Return On Equity yang dimana adalah perbandingan antara laba bersih dan modal.

Likuiditas adalah berhubungan dengan kemampuan suatu perusahaan untuk memenuhi kewajiban financial jangka pendeknya yang segera harus dipenuhi. Kemampuan tersebut merupakan kemampuan perusahaan dalam melanjutkan operasionalnya ketika perusahaan tersebut diwajibkan untuk melunasi kewajibannya yang akan mengurangi dana operasionalnya (Farisa \& Widati, 2017). Ukuran perusahaan menggambarkan besar kecilnya suatu perusahaan dimana perusahaan yang besar akan lebih mudah mendapatkan pinjaman dari luar dibandingkan dengan perusahaan kecil. Semakin besar ukuran perusahaan ada kecenderungan untuk menggunakan jumlah pinjaman yang cukup besar dibandingkan dengan perusahaan kecil (Fahmi L. Z., 2017). Penentuan besar kecilnya ukuran perusahaan dapat ditentukan berdasarkan total penjualan, total aktiva, rata-rata tingkat penjualan, dan rata-rata total aktiva (Seftianne, 2011).

Penelitian ini dilakukan pada perusahaan property dan real estate karena sektor ini merupakan salah satu alternatif investasi yang diminati investor dimana investasi di sektor ini merupakan investasi jangka panjang dan properti merupakan aktiva multiguna yang dapat digunakan oleh perusahaan sebagai jaminan. Oleh karena itu, perusahaan property dan real estate mempunyai struktur modal yang tinggi. Sektor propertydan real estate merupakan sektor yang paling rentan dalam industri makro terhadap fluktuasi suku bunga, inflasi dan nilai tukar yang pada akhirnya akan mempengaruhi pada daya beli masyarakat. Bahkan bagi sebagian orang justru digunakan untuk menyembunyikan dan memutar uang. Perusahaan property dan real estate merupakan salah satu sektor industri yang terdaftar di Bursa Efek Indonesia 
(BEI). Perkembangan industri property dan real estate begitu pesat saat ini dan akan semakin besar di masa yang akan datang. Hal ini disebabkan oleh semakin meningkatnya jumlah penduduk sedangkan supply tanah bersifat tetap. Perusahaan yang mampu bertahan adalah perusahaan yang memiliki struktur modal kuat, maka industri properti saat ini juga seharusnya memiliki kebijakan struktur modal yang dapat membuatnya bertahan pada masa krisis global yang terjadi pada empat tahun terakhir ini. Oleh karena itu, untuk melakukan penelitian ini peneliti mengambil judul pengaruh profitabilitas, likuiditas, ukuran perusahaan terhadap struktur modal pada perusahaan property dan real estate di Bursa Efek Indonesia (BEI).

Berdasarkan hasil dari laporan keuangan perusahaan property dan real estate dapat diketahui Profitabilitas yang dilihat dari laba bersih di tahun 2016 sebesar 939,7 Miliar rupiah mengalami penurunan $0,15 \%$ dibandingkan dengan tahun 2015 sebesar 1,116 Triliun rupiah pada PT Agung Podomoro Land Tbk. Sedangkan Struktur Modal yang dilihat dari Total Hutang di tahun 2015 sebesar 15,486 Triliun rupiah mengalami kenaikan sebesar 0,01\% ditahun 2016 sebesar 15,741 Triliun rupiah. Keadaan ini menunjukkan bahwa penurunan profitabilitas tidak selalu diikuti dengan kenaikan Total Hutang.

Pada PT. Duta Anggada Realty Tbk pada Likuiditas yang dilihat dari Aktiva Lancar tahun 2017 sebesar 357,5Miliar rupiah mengalami penurunan $0,08 \%$ dibandingkandengan tahun 2016 sebesar 389,9Miliar rupiah pada PT Duta Anggada Realty Tbk. Sedangkan Struktur modal yang dilihat dari Total Hutang di tahun 2016 sebesar 2,442 Triliun rupiah mengalami kenaikan sebesar $0,14 \%$ di tahun 2017 sebesar 2,801 Triliun rupiah. keadaan ini menunjukkan bahwa penurunan Likuiditas tidak selalu diikuti dengan kenaikan Total Hutang.

Pada PT. Bekasi Fajar Industrial Estate Tbk pada Ukuran Perusahaan yang dilihat dari Total Aktiva tahun 2017 sebesar5,719 Triliun rupiah mengalami kenaikan 0,09\% di tahun 2018 sebesar 6,290 Triliun rupiah sedangkan Struktur modal yang dilihat dari Total Hutang pada tahun 2017 sebesar 1,870 Triliun rupiah juga mengalami kenaikkan $0,13 \%$ di tahun 2018 sebesar 2,118 Triliun rupiah. Dari hasil fenomena laporan keuangan perusahaan Property dan Real Estate mengalami ketidakstabilan dan dapat disimpulkan bahwa penurunan profitabillitas, likuiditas, dan ukuran perusahaan tidak selalu diikuti dengan kenaikan Total Hutang.

\subsection{RumusanMasalah}

Adapun rumusan masalah yang terdapat dalam penelitian ini berupa aoakah profitabilitas berpengaruh terhadap struktur modal, melihat pengaruh likuiditas terhadap struktur modal, dan ukuran perusahaan terhadap struktur modal atau tidak.

\section{TINJAUANPUSTAKA \\ 2.1 Profitabilitas}

Tingginya biaya modal dapat diakibatkan oleh suatu keputusan yang cerdas dan cermat. Sehingga dapat mempengaruhi rendahnya Profitabilitas dan mengancam posisi financial sebuah perusahaan (Qusibah \& Yusra, 2019). Menurut (Atmojo \& Susilowati, 2019) indikator yang digunakan untuk menghitung profitabilitas yaitu ROE. Dimana Return On Equity adalah laba atas ekuitas. Rasio ini menggambarkan sejauh mana suatu perusahaan dapat menggunakan sumber daya yang dimiliki untuk mampu menghasilkan laba atas ekuitas.Untuk menghitung rasio ini dapat menggunakan rumus : 
Return On Equity $=\frac{\text { Laba Setelah Pajak }}{\text { Modal Sendiri }}$

\subsection{Likuiditas}

(Dewi, Suci, \& Mahardika, 2019) menyebutkan bahwa rasio likuiditas merupakan rasio yang menggambarkan kemampuan perusahaan untuk memenuhi kewajiban utang jangka pendek dengan asset lancar yang dimilikinya. Tingkat likuiditas dapat diukur dengan menggunakan indikator Current Ratio dengan rumus sebagai berikut :

$$
\text { Current Ratio }=\frac{\text { Aktiva Lancar }}{\text { Hutang Lancar }}
$$

\subsection{Ukuran Perusahaan}

(Ayu Melyani, Suci, \& Cipta, 2019) untuk mendapatkan nilai ukuran perusahaan yang tinggi, perusahaan perlu menambah asetnya dengan cara mendapatkan pinjaman untuk membeli asset baru. Ukuran Perusahaan dapat diukur menggunakan rumus sebagai berikut :

\section{Ukuran Perusahaan $=$ Log Total Aktiva}

\subsection{Struktur Modal}

Struktur modal yang optimal yang mampu menghasilkan biaya modal paling terendah maka akan memaksimumkan nilai perusahaan (Septiani \& Suaryana, 2018). Menurut (Cahyani, 2017) struktur modal diukur dengan skala rasio Debt to Equity Ratio (DER). Rasio ini menunjukkan komposisi dari total hutang terhadap total ekuitas menggunakan rumus sebagai berikut :

\section{Debt to Equity Ratio= $=\frac{\text { Total Hutang }}{\text { Total Ekuitas }}$}

\subsection{Pengaruh Profitabilitas Terhadap Struktur Modal}

(Maha Dewi \& Sudiartha, 2017) menyatakan bahwa setiap peningkatan profitabilitas maka akan selalu diikuti dengan kenaikan struktur modal. Dimana semakin tinggi profitabilitas, maka akan semakin besar laba yang ditahan tetapi akan diimbangi dengan utang yang tinggi karena prospek perusahaan dianggap sangat bagus.

(Weko Hartoyo, Khafid, \& Agustina, 2014) mengatakan bahwa besarnya profitabilitas suatu perusahaan maka semakin besar pula struktur modalnya. Dengan kata lain, kondisi keuangan perusahaan yang baikakan meminjam uang lebih sedikit, tetapi akan menimbulkan ketertarikan investor dalam menanamkan modalnya.

Pengaruh profitabilitas secara umum terhadap struktur modal dapat disimpulkan jika profitabilitas suatu perusahaan meningkat otomatis semakin besar pula struktur modal yang di perlukan.

$\mathrm{H}_{1} \quad$ : Profitabilitas berpengaruh terhadap struktur modal

\subsection{Pengaruh \\ Likuiditas} Terhadap Struktur Modal

(Septiani \& Suaryana, 2018) mengatakan bahwa semakin besar likuiditas yang dimiliki perusahaan maka semakin kecil dana eksternal khususnya utang yang digunakan perusahaan, sehingga akan menurunkan struktur modal. Jika perusahaan dengan likuiditas yang tinggi akan cenderung tidak menggunakan pembiayaan dari utang.

(Bhawa \& Dewi S, 2015) menyatakan bahwa semakin tinggi kemampuan perusahaan dalam mengembalikan kewajiban-kewajiban jangka pendeknya maka semakin likuid perusahaan tersebut. Dengan begini akan membangun kepercayaan dari kreditur meningkat dan mempermudah perusahaan memperoleh utang jangka panjang.

(Cahyani, 2017) mengungkapkan bahwa perusahaan dengan likuiditas yang tinggi mempunyai dana internal yang cukup besar. Perusahaan akan lebih memilih menggunakan dana internalnya terlebih dahulu sebelum menggunakan dana eksternal atau hutang untuk 
menjalankan operasional perusahaan.

Pengaruh Likuiditas secara umum terhadap struktur modal dapat disimpulkan bahwa Likuiditas yang baik pada perusahaan akan menghasilkan hutang yang kecil sehingga akan membangun kepercayaan pada investor untuk menanam modalnya.

$\mathrm{H}_{2} \quad$ : Likuiditas berpengaruh terhadap struktur modal.

\subsection{Pengaruh Ukuran Perusahaan Terhadap Struktur Modal}

(Sari \& Oetomo, 2016) mengatakan bahwa kenaikan ukuran perusahaan akan diikuti dengan kenaikan struktur modal. Dimana semakin besar perusahaan maka kecenderungan dalam menggunakan dana eksternal juga akan semakin besar.

(Denziana \& Yunggo, 2017) menyatakan bahwa semakin besar ukuran suatu perusahaan, maka kecenderungan akan menggunakan modal asing juga semakin besar. Perusahaan yang besar membutuhkan dana yang besar pula untuk menunjang operasional perusahaan tersebut, salah satu alternative lainnya dengan modal asing apabila modal sendiri sudah tidak mencukupi.

(Zuhro MB, 2016) mengemukakan bahwa perusahaan mempunyai ukuran yang besar maka kemungkinan dipercayakan untuk mendapatkan sumber dana yang cukup sehingga mampu mendapatkan kredit dari pihak luar.

Secara umum pengaruh Ukuran Perusahaan terhadap struktur modal dapat disimpulkan bahwa Ukuran Perusahaan yang besar berarti selalu memerlukan asupan dana dari pihak luar.

$\mathrm{H}_{3} \quad$ : Ukuran Perusahaan berpengaruh terhadap struktur modal.

III. METODE PENELITIAN

\subsection{Metodologi Penelitian}

Metode penelitian ini dilakukan pada perusahaan property dan real estate yang terdaftar di Bursa Efek Indonesia periode 2015-2018. Penelitian ini menggunakan metode penelitian kuantitatif. Jenis penelitian yang digunakan adalah penelitian statistik deskriptif dan sifat penelitian ini adalah hubungan kausal dimana menjelaskan hubungan sebab akibat antara variabel bebas dengan variabel terikat

\subsection{Populasi dan Sampel}

Populasi dalam penelitian ini adalah perusahaan Property dan Real Estate. Berdasarkan populasi yang sudah ditentukan terdapat 61 perusahaan. Populasi adalahwilayah generalisasi yang terdiri atas sebuah obyek atau subyek yang memiliki kualitas dan karakteristik tertentu yang akan ditetapkan oleh peneliti untuk dipelajari dan kemudian ditarik hasil kesimpulannya (Sugiyono, 2017).

Pengambilan sampel penelitian ini dengan menggunakan purposive sampling yaitu teknik pengambilan sampel berdasarkan dengan kriteriakriteria sebagai berikut :

1. Perusahaan Property dan Real Estate yang terdaftar di Bursa Efek Indonesia tahun 2015-2018.

2. Perusahaan Property dan Real Estate yang terdaftar di Bursa Efek Indonesia tahun 2015-2018.

3. Perusahaan Property dan Real Estate yang terdaftar di Bursa Efek Indonesia tahun 2015-2018.

Tabel 1. Kriteria Pengambilan Sampel Penelitian

\begin{tabular}{|c|l|c|}
\hline No. & \multicolumn{1}{|c|}{ Kriteria } & $\begin{array}{c}\text { Jumlah } \\
\text { Sampel }\end{array}$ \\
\hline 1 & $\begin{array}{l}\text { Perusahaan property dan } \\
\text { real estate yang terdaftar } \\
\text { di Bursa Efek Indonesia } \\
\text { tahun 2015-2018. }\end{array}$ & 61 \\
\hline 2 & $\begin{array}{l}\text { Perusahaan property dan } \\
\text { real estate yang tidak } \\
\text { mempublikasikan } \\
\text { laporan keuangan secara } \\
\text { lengkap di Bursa Efek } \\
\text { Indonesia pada tahun } \\
\text { 2015-2018. }\end{array}$ & (13) \\
\hline 3 & $\begin{array}{l}\text { Perusahaan property dan } \\
\text { real estate yang tidak }\end{array}$ & (20) \\
\hline
\end{tabular}




\begin{tabular}{|c|c|}
\hline $\begin{array}{c}\text { melaporkan laba bersih } \\
\text { pada tahun 2015-2018. }\end{array}$ & \\
\hline Jumlah Sampel & 28 \\
\hline $\begin{array}{c}\text { Jumlah Pemilihan Sampel (4 } \\
\text { tahun x 28) }\end{array}$ & 112 \\
\hline
\end{tabular}

\section{Hasil dan Pembahasan}

\subsection{Statistik Deskriptif}

Berdasarkan data sampel yang diperoleh maka dilakukan analisis statistik deskriptif untuk mengetahui nilai rata-rata (mean) dan standar deviasi (standart deviation) setiap variabel. Hasil analisis deskriptif dapat dilihat di bawah ini sebagai berikut:

Tabel 2. Statistik Deskriptif

Descriptive Statistics

\begin{tabular}{|l|r|r|r|}
\hline & \multicolumn{1}{c|}{ Mean } & \multicolumn{1}{c|}{$\begin{array}{c}\text { Std. } \\
\text { Deviation }\end{array}$} & \multicolumn{1}{c|}{ N } \\
\hline LN_SM &,- 4550 &, 76179 & 111 \\
\hline LN_ROE & $-2,6822$ & 1,08673 & 111 \\
\hline LN_CR &, 7411 &, 71309 & 111 \\
\hline LN_UK & 3,3842 &, 05136 & 111 \\
\hline
\end{tabular}

\subsection{Hasil Uji Asumsi Klasik :}

\subsubsection{Uji Normalitas}

(Ghozali, 2018) menyatakan bahwa uji normalitas bertujuan untuk mengetahui variabel

pengganggu atau nilai residual apakah berdistribusi normal atau tidak. Penelitian ini menggunakan uji Histogram, Scatterplot dan kolmogorov-smirnov. Jika nilai signifikansi $>0,05$ maka data residual berdistribusi normal. Hasil dari pengujiannya adalah sebagai berikut :

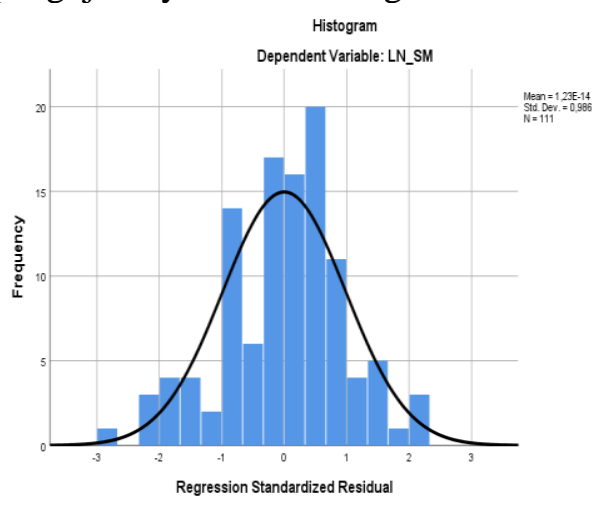

Gambar 1. Grafik Uji Normalitas Histrogram (Setelah Transformasi)

Grafik histogram diatas merupakan grafik yang telah mengalami transformasi data sehingga dapat dilihat bahwa grafik diatas menunjukkan data distribusi normal karena kurva normal yaitu membentuk lonceng sempurna( $\mathrm{U}$ terbalik), tidak melenceng kekiri dan tidak melenceng kekanan. Grafik histogram yang baik yaitu grafik yang memulai garis kurva pada sumbu y dari angka 0 , sehingga dapat disimpulkan bahwa grafik histogram tersebut berdistibusi normal.

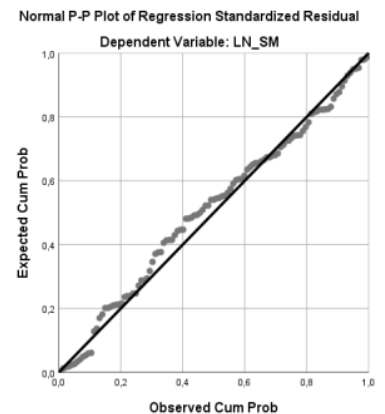

Gambar 2. Grafik Uji Normalitas P-Plot (Setelah Transformasi)

Berdasarkan grafik normalitas PP Plot di atas, dapat dilihat titik-titik menyebar mengikuti garis diagonal, sehingga dapat disimpulkan bahwa data dalam model regresi telah memenuhi asumsi normalitas dan berdistribusi normal.

Tabel 3. Uji Normalitas KolmogrovSmirnov (Setelah transformasi)

\section{ne-Sample Kolmogorov-Smirnov Test}

\begin{tabular}{|c|c|c|}
\hline & & $\begin{array}{l}\text { Unstand. } \\
\text { Residual }\end{array}$ \\
\hline \multirow{4}{*}{ ormal Parameters ${ }^{\mathrm{a}, \mathrm{b}}$} & & 111 \\
\hline & Mean & ,0000000 \\
\hline & Std. & 63230079 \\
\hline & Deviation & \\
\hline \multirow{3}{*}{$\begin{array}{l}\text { lost Extreme } \\
\text { ifferences }\end{array}$} & Absolute & ,075 \\
\hline & Positive & ,050 \\
\hline & Negative &,- 075 \\
\hline
\end{tabular}




\begin{tabular}{|l|l|}
\hline Kolmogrov-Smirnov Z &, 075 \\
Asymp. Sig. (2-tailed) &, $156^{\mathrm{c}}$ \\
\hline
\end{tabular}

a. Test distribution is Normal.

b. Calculated from data.

c. Lilliefors Significance Correction.

Berdasarkan hasil uji statistik Kolmogrov Smirnov $\mathrm{Z}$ adalah sebesar 0,075 dan tidak signifikan pada 0,05 (karena Asymp $\mathrm{p}=0,156>$ dari 0,05 ) sehingga dapat diketahui bahwa Return On Equity $\left(\mathrm{X}_{1}\right)$, Current Ratio $\left(\mathrm{X}_{2}\right)$, Ukuran Perusahaan $\left(\mathrm{X}_{3}\right)$ dan Struktur Modal (Y) berdistribusi normal karena nilai signifikan sebesar 0,156>0,05 maka residual berdistribusi normal.

\subsubsection{Uji Multikolinearitas}

(Ghozali, 2018) menyatakan bahwa uji ini digunakan untuk mengetahui ada tidaknya ditemukan hubungan kuat antar variabel bebas (independen). Apabila tolerance value> 0,1 atau VIF < 10, maka disimpulkan tidak terjadi multikolinearitas. Hasil dari pengujian multikolinearitas yang digunakan dalam penelitian ini adalah sebagai berikut :

Tabel 4.Uji Multikolinearitas Coeficients $^{\text {a }}$

\begin{tabular}{|ll|l|l|}
\hline \multirow{2}{*}{ Model } & \multicolumn{2}{|l|}{ Collinearity Statistics } \\
\cline { 2 - 3 } 1 (Constant) & & Tolerance & VIF \\
\hline \multirow{2}{*}{ LN_ROE } &, 976 & 1,024 \\
\hline LN_CR &, 985 & 1,015 \\
\hline LN_UK &, 991 & 1,009 \\
\hline
\end{tabular}

a. Dependent Variable: LN_SM

Berdasarkan tabel

uji

multikolinearitas diatas dapat disimpulkan bahwa nilai tolerancevalue yang diperoleh untuk setiap variabel lebih besar dari 0,10 dan nilai VIF yang diperoleh untuk setiap variabel lebih kecil dari 10, maka artinya dapat disimpulkan bahwa data variabel Return On Equity $\left(\mathrm{X}_{1}\right)$, Current Ratio $\left(\mathrm{X}_{2}\right)$, Ukuran Perusahaan $\left(\mathrm{X}_{3}\right)$ dan Struktur Modal tidak terjadi multikolinearitas.
Untuk dapat mengetahui apakah model regresi linear adanya korelasi terhadap periode $\mathrm{t}$ dengan periode $\mathrm{t}-1$ (sebelumnya), (Ghozali, 2018). Uji ini dapat diukur berdasarkan nilai Durbin Watson yang diperoleh, jika $\mathrm{du}<\mathrm{dw}<4-$ du, maka dapat disimpulkan tidak terjadi masalah autokorelasi.

Tabel 5.Uji Autokorelasi Setelah Transformasi

Model Summary $^{\mathrm{b}}$

\begin{tabular}{|c|c|c|c|c|c|}
\hline Model & $\mathrm{R}$ & $\begin{array}{c}\mathrm{R} \\
\text { Square }\end{array}$ & $\begin{array}{c}\text { Adjusted } \\
\text { R } \\
\text { Square }\end{array}$ & $\begin{array}{c}\text { Std. } \\
\text { Error of } \\
\text { the } \\
\text { Estimate }\end{array}$ & $\begin{array}{l}\text { Durbin- } \\
\text { Watson }\end{array}$ \\
\hline 1 &, $558^{\mathrm{a}}$ & ,311 & ,292 & 64110 & 2,188 \\
\hline
\end{tabular}

a. Predictors: (Constant), LN_UK, LN_CR, LN_ROE

b. Dependent Variable: LN_SM

Berdasarkan tabel uji autokorelasi di atas, dapat disimpulkan bahwa nilai DW yang diperoleh adalah sebesar 2,188. Nilai D-W menurut tabel $\mathrm{K}=3$ dan $\mathrm{N}=111$ didapat nilai $\mathrm{dl}=1,6355$ dan nilai $\mathrm{du}=$ 1,7463 sehingga $\mathrm{du}<\mathrm{dw}<4-\mathrm{du}$ memenuhi syarat yaitu 2,2537. Maka $(1,7463 \leq 2,188 \leq 2,2537)$ dapat disimpulkan tidak terjadi autokorelasi.

\subsubsection{Uji Heterokedastisitas}

Bertujuan untuk menguji apakah dalam model regresi terjadi ketidaksamaan varian didalam grafik scatterplot dari residual satu pengamatan ke pengamatan lainnya (Ghozali, 2018). Kriteria pengujian scatterplot dapat dilihat dengan titik-titik yang menyebar secara acak baik diatas maupun dibawah angka nol (0) pada sumbu Y.

\subsubsection{Uji Autokorelasi}




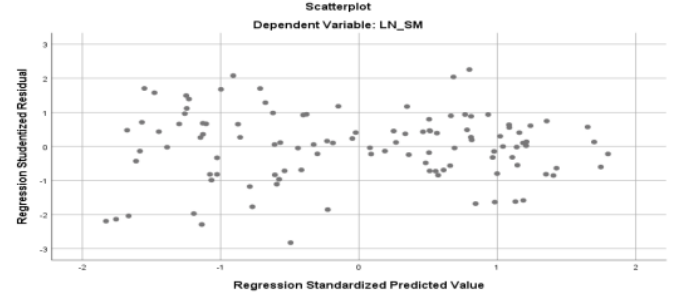

Gambar 3. Grafik Uji

Heterokedastisitas Scatterplot (Setelah Transformasi)

Berdasarkan gambar diatas dapat dilihat bahwa titik-titik menyebar secara acak baik diatas maupun dibawak angka 0 pada sumbu Y dan tidak membentuk pola tertentu. Sehingga dapat disimpulkan bahwa tidak terjadi heteroskedatisitas pada model regresi.

Pengujian ada tidaknya heterokedastisitas dapat juga dilakukan dengan menggunakan metode uji Glejser, yaitu dengan cara meregresikan nilai absolute residual terhadap variabel independen

Tabel 6.Uji Glejser (Ln) Setelah Transformasi

Coefficients $^{\mathrm{a}}$

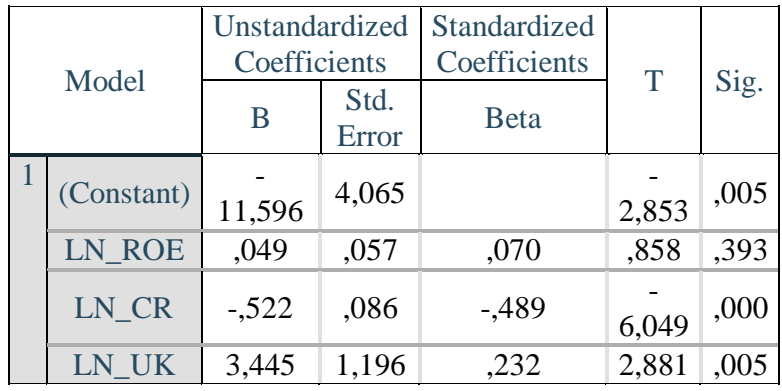

Berdasarkan tabel uji glejser (Ln) diatas menunjukkan bahwa Return On Equity memiliki tingkat signifikan yang lebih besar dari 0,05 maka dapat disimpukan bahwa tidak terjadi gejala heterokedatisitas, sedangkan Current Ratio dan Ukuran Perusahaan memiliki tingkat signifikan kurang dari 0,05 maka dapat disimpulkan terjadi gelaja heterokedatisitas.

\subsection{Hasil Analisis Data Penelitian \\ Pengujian hipotesis penelitian} dapat dilakukan dengan menggunakan analisis regresi linear berganda. Berikut ini adalah model regresi yang dapat digunakan untuk menganalisis data :

\section{Tabel 7.Persamaan Regresi}

\section{Coefficients $^{\mathrm{a}}$}

\begin{tabular}{|c|c|c|c|c|c|c|}
\hline \multicolumn{2}{|c|}{} & \multicolumn{2}{|c|}{$\begin{array}{c}\text { Unstandardize } \\
\text { d Coefficients }\end{array}$} & $\begin{array}{c}\text { Stand. } \\
\text { Coef. }\end{array}$ & \multirow{2}{*}{ T } & \multirow{2}{*}{ Sig. } \\
\cline { 2 - 7 } & B & $\begin{array}{c}\text { Std. } \\
\text { Error }\end{array}$ & Beta & & \\
\hline 1 & $\begin{array}{c}\text { (Constan } \\
\text { t) }\end{array}$ & $\begin{array}{c}- \\
11,596\end{array}$ & $\begin{array}{c}4,06 \\
5\end{array}$ & & $-2,853$ &, 005 \\
\cline { 2 - 7 } & $\begin{array}{c}\text { LN_RO } \\
\text { E }\end{array}$ &, 049 &, 057 &, 070 &, 858 &, 393 \\
\cline { 2 - 7 } & LN_CR &,- 522 &, 086 &,- 489 & $-6,049$ &, 000 \\
\hline & LN_UK & 3,445 & $\begin{array}{c}1,19 \\
6\end{array}$ &, 232 & 2,881 &, 005 \\
\hline
\end{tabular}

Berdasarkan tabel diatas diperoleh rumus regresi sebagai berikut :

LNSTRUKTUR MODAL $=-11,596+$ 0,049 LNROE - 0,522 LNCR + 3,445 LNUK

Berdasarkan nilai dari persamaan regresi linear di atas maka koefisienkoefisien tersebut dapat disimpulkan sebagai berikut :

1. Nilai konstanta ( $\alpha$ ) sebesar $-11,596$ yang menunjukkan apabila variabel LN_ROE $\left(\mathrm{X}_{1}\right)$, LN_CR $\left(\mathrm{X}_{2}\right)$, dan LN_UK $\left(\mathrm{X}_{3}\right)$ sama dengan 0 maka Struktur Modal akan mengalami penurunan sebesar -11,596 satuan.

2. Pada koefisien $\beta 1$ sebesar 0,049 menunjukkan adanya pengaruh positif antara variabel $\mathrm{ROE}\left(\mathrm{X}_{1}\right)$ terhadap struktur modal (Y). Dimana bahwa setiap kenaikan ROE satu satuan akan menyebabkan kenaikkan Struktur Modal sebesar 0,049 satuan.

3. Pada koefisien $\beta 2$ sebesar $-0,522$ menunjukkan adanya pengaruh negatif antara variabel $\mathrm{CR}\left(\mathrm{X}_{2}\right)$ terhadap struktur modal (Y). Dimana 
bahwa setiap kenaikan CR satu satuan akan mengakibatkan penurunan Struktur Modal sebesar 0,522 satuan.

4. Pada koefisien $\beta 3$ sebesar 0,3445 menunjukkan adanya pengaruh positif antara variabel UK $\left(\mathrm{X}_{3}\right)$ terhadap struktur modal (Y). Dimana setiap kenaikan UK satu satuan akan mengakibatkan kenaikkan Struktur Modal sebesar 0,3445 satuan.

\subsection{Koefisien Determinasi Hipotesis}

(Ghozali, 2018) menyatakan bahwa koefisien determinasi digunakan untuk dapat memprediksi sebesarapa besar pengaruh variabel $\mathrm{x}$ secara simultan terhadap variabel y. Dimana criteria pengujiannya menggunakan nilai $\mathrm{R}^{2}$ yang mendekati 0 berarti variabel bebas tidak menjelaskan mengenai variabel terikat, sebaliknya apabila $\mathrm{R}^{2}$ mencapai angka 1 berarti variabel bebas memberikan penjelasan memprediksi variabel terikat.

Tabel 8.Koefisien Determinasi

\begin{tabular}{|c|c|c|c|c|}
\hline \multicolumn{5}{|c|}{ Model Summaryb } \\
\hline Model & $R$ & $\begin{array}{l}\mathrm{R} \\
\text { Square }\end{array}$ & $\begin{array}{l}\text { Adjusted } \\
\text { R Square }\end{array}$ & $\begin{array}{l}\text { Std. } \\
\text { Error of } \\
\text { the } \\
\text { Estimate }\end{array}$ \\
\hline 1 &, $558^{\mathrm{a}}$ & 311 & ,292 & ,64110 \\
\hline
\end{tabular}

a. Predictors: (Constant), LN_UK, LN_CR, LN_ROE

b. Dependent Variable: LN_SM

Berdasarkan hasil uji koefisien determinasi diatas dapat dilihat bahwa nilai Adjusted $R$ Square $\left(\mathrm{R}_{2}\right)$ sebesar 0,292 atau sama dengan $29,2 \%$. Hal ini berarti variabel Return On Equity, Current Ratio, Ukuran Perusahaan mampu menjelaskan variabel Struktur Modal sebesar 29,2\% . Selebihnya sebesar 0,64110 atau $64,1 \%$ dijelaskan oleh variabel lainnya.

\subsection{Pengujian Hipotesis Secara Simultan (Uji F)}

Uji $F$ digunakan untuk menunjukkan apakah variabel independen mempunyai pengaruh .bersama-sama terhadap variabel dependen.

Tabel 9 .Uji Statistik F

ANOVA
\begin{tabular}{|ll|l|l|}
\hline Model & F & Sig. \\
\hline \multirow{2}{*}{1} & Regression & 16,105 &, $000^{\mathrm{b}}$ \\
\cline { 2 - 4 } & Residual & & \\
\hline & Total & & \\
\hline
\end{tabular}

a. Dependent Variable: LN_SM

b. Predictors: (Constant), LN_UK, LN_CR, LN_ROE

Berdasarkan tabel uji $\mathrm{F}$ diatas dapat dilihat bahwa uji signifikan simultan menghasilkan nilai $F_{\text {hitung }}$ sebesar 16,105 dengan $\mathrm{F}_{\text {tabel }}$ yaitu 2,69 dengan nilai signifikan $0,000<0,05$. Maka dapat disimpulkan bahwa variabel Profitabilitas, Likuiditas, Ukuran Perusahaan berpengaruh secara simultan dan signifikan terhadap variabel dependen yaitu struktur modal padaperusahaan property dan real estate yang terdaftar di Bursa Efek Indonesia periode 2015-2018 .

\subsection{Pengujian Hipotesis Secara Parsial (Uji t)}

Uji t digunakan untuk mengetahui tingkat signifikan pengaruh variabel bebas secara parsial yang dikemukankan oleh (Ghozali, 2018). Kriteria pengujiannya adalah $\mathrm{t}$ hitung $>\mathrm{t}$ tabel dengan nilai yang siginifikan 0,05. Hasil pengujiannya adalah sebagai berikut :

Tabel 10.Uji t

\begin{tabular}{|l|l|l|l|}
\hline \multicolumn{3}{|c|}{ Coefficients $^{\mathrm{a}}$} \\
\hline \multirow{2}{*}{ Model } & & $\mathrm{T}$ & Sig. \\
\hline \multirow{2}{*}{1} & (Constant) & $-2,853$ &, 005 \\
\cline { 2 - 4 } & LN_ROE &, 858 &, 393 \\
\cline { 2 - 4 } & LN_CR & $-6,049$ &, 000 \\
\cline { 2 - 4 } & LN_UK & 2,881 &, 005 \\
\hline \multicolumn{4}{|c|}{ a. Dependent Variable: LN_SM } \\
\hline
\end{tabular}

Dari tabel diatas dapat disimpulkan bahwa 
1. Variabel Profitabilitas yang dilihatdari Return On Equity memiliki nilai $t_{\text {hitung }}$ sebesar 0,858 dan $t_{\text {tabel }} 1,659$ dengan nilai signifikan $0,393>0,05$. Dimana didapatkan $\mathrm{t}_{\text {hitung }}<\mathrm{t}_{\text {tabel }}$ yaitu $0,858<1,659$ dan nilai signifikan lebih besar dari 0,05 maka hipotesis 1 ditolak, yang artinya variabel Profitabilitas secara parsial berpengaruh negatif dan tidak signifikan terhadap struktur modal pada perusahaan property dan real estate yang terdaftar di Bursa Efek Indonesia periode 2015-2018.

2. Variabel Likuiditas yang dilihat dari Current Ratio memiliki nilai thitung sebesar -6,049 dan $t_{\text {tabel }}$ sebesar 1,659 dengan nilai signifikan $0,000<0,05$. Dimana didapatkan $t_{\text {hitung }}<\mathrm{t}_{\text {tabel }}$ yaitu $-6,049<1,659$ dan nilai signifikan lebih kecil dari 0,05 maka hipotesis 2 ditolak, artinya Current Ratio berpengaruh negatif dan tidak signifikan terhadap struktur modal pada perusahaan property dan real estate yang terdaftar di Bursa Efek Indonesia periode 2015-2018.

3. Variabel Ukuran Perusahaan memiliki nilai $t_{\text {hitung }}$ sebesar 2,881 dan $t_{\text {tabel }}$ sebesar 1,659 dengan nilai signifikan $0,005<0,05$. Dimana didapatkan $\quad \mathrm{t}_{\text {hitung }}>\mathrm{t}_{\text {tabel }} \quad$ yaitu $2,881>1,659$ dan nilai signifikan lebih kecil dari 0,05 maka hipotesis 3 diterima, yang artinya Ukuran Perusahaan berpengaruh positif signifikan terhadap struktur modal pada perusahaan property dan real estate yang terdaftar di Bursa Efek Indonesia periode 2015-2018.

\subsection{Pembahasan Pengaruh Profitabilitas Terhadap Struktur Modal}

Berdasarkan hasil penelitian yang telah dilakukan maka dapat diperoleh hasil bahwa nilai profitabilitas terhadap struktur modal yang diperoleh dari nilai $t_{\text {hitung }}<t_{\text {tabel }}$ yaitu $0,858<1,659$ yang menyatakan bahwa profitabilitas secara parsial berpengaruh negatif dan tidak signifikan terhadap struktur modal pada perusahaan property dan real estate yang terdaftar di Bursa Efek Indonesia periode 2015-2018. Hal ini terjadi karena perusahaan telah menetapkan struktur modalnya berdasarkan besarnya manfaat dan pengorbanan yang timbul sebagai akibat dari penggunaan hutang untuk mendukung operasional perusahaan. Hasil penelitian ini sejalan dengan penelitian yang dilakukan oleh (Purwana, Titisari, \& Suhendro, 2019) yang mengatakan variabel profitabilitas menunjukkan bahwa profitabilitas tidak berpengaruh terhadap struktur modal sedanggkan hasil penelitian

ini betolak belakang dengan penelitian yang dilakukan oleh Cahyo (2014) yang mengemukakan bahwa variabel profitabilitas berpengaruh positif signifikan terhadap struktur modal.

\subsection{Pembahasan Pengaruh Likuiditas Terhadap Struktur Modal}

Dari hasil pengolahan data diperoleh hasil $\mathrm{t}$ hitung $<\mathrm{t}$ tabel pada variabel likuiditas yaitu sebesar -6,049< 1,659, maka dari itu dapat disimpulkan bahwa likuiditas berpengaruh negatif dan tidak signifikan terhadap struktur modal. Artinya Likuiditas suatu perusahaan tidak menjadi pertimbangan khusus bagi para investor untuk menanamkan modalnya. Karena setiap penurunan ataupun kenaikan dari likuiditas tidak mempengaruhi struktur modal perusahaan. Hasil penelitian ini sejalan dengan penelitian yang dilakukan oleh (Widayanti, Triaryati, \& Abundanti, 2016) semakin tinggi likuiditas maka tingkat struktur modal perusahaan akan menurun. Artinya, jika perusahaan yang mempunyai likuiditas tinggi berarti mempunyai kemampuan membayar 
hutang jangka pendek, sehingga cenderung akan menurunkan total hutang, yang akhirnya struktur modal akan menjadi lebih kecil. Dan tidak sejalan dengan penelitian yang dilakukan oleh (Bhawa \& Dewi S, 2015) dalam penelitiannya mengatakan bahwa likuiditas berpengaruh positif signifikan terhadap struktur modal.

\subsection{Pembahasan Pengaruh Ukuran Perusahaan Terhadap Struktur Modal}

Dari hasil penelitian yang dilakukan pada variabel ukuran perusahaan terhadap struktur modal dapat diperoleh nilai $t_{\text {hitung }}>t_{\text {tabel }}$ yaitu 2,881 > 1,659 yang menyatakan ukuran perusahaan secara parsial berpengaruh positif signifikan terhadap struktur modal pada perusahaan property dan real estate yang terdaftar di Bursa Efek Indonesia periode 2015-2018. Hal ini menandakan perusahaan yang besar memiliki saham perusahaan yang tersebar luas. Setiap perluasan modal saham hanya akan mempunyai pengaruh yang kecil terhadap kemungkinan hilangnya atau bergesernya pengendalian perusahaan yang dominan terhadap perusahaan yang bersangkutan. Hasil penelitian ini sejalan dengan penelitian yang dilakukan oleh (Rahmiati, Yumna, \& Gusti, 2016) akan tetapi, tidak sejalan dengan penelitian yang dilakukan oleh (Krisnanda \& Wiksuana, 2015) yang menyatakan bahwa ukuran perusahaan tidak berpengaruh positif signifikan terhadap struktur modal.

\section{KESIMPULAN DAN SARAN 5.1 Kesimpulan}

Penelitian ini menguji bagaimana pengaruh Profitabilitas, Likuiditas, Ukuran Perusahaan terhadap struktur modal pada perusahaan property dan real estate yang terdaftar di Bursa Efek
Indonesia periode 2015-2018. Dari hasil penelitian dapat disimpulkan bahwa :

Profitabilitas secara parsial berpengaruhnegatif dan tidak signifikan terhadap struktur modal pada perusahaan property dan real estate yang terdaftar di Bursa Efek Indonesia periode 2015-2018.

Likuiditas secara parsial berpengaruh negatif dan tidak signifikan terhadap struktur modal pada perusahaan property dan real estate yang terdaftar di Bursa Efek Indonesia periode 2015-2018.

Ukuran Perusahaan berpengaruh positif signifikan terhadap struktur modal pada perusahaan property dan real estate yang terdaftar di Bursa Efek Indonesia periode 2015-2018.

\subsection{Saran}

Berdasarkan kesimpulan diatas maka saran yang dapat disampaikan adalah Penelitian selanjutnya diharapkan untuk menggunakan variabel lain yang dapat mempengaruhi struktur modal yang tidak dijelaskan dalam penelitian ini seperti risiko bisnis, struktur aktiva, ataupun pertumbuhan aset, dan lain-lain. Dikarenakan hanya ukuran perusahaan yang cenderung positif maka Sebaiknya, perusahaan memiliki kecukupan kapitalisasi untuk mampu bertahan. Karena semakin besar kapitalisasi suatu perusahaan, maka semakin besar ukuran perusahaan dan perusahaan akan dinilai semakin mampu dalam memenuhi kebutuhannya untuk membiayai pertumbuhan yang didasarkan pada penjualan. Bagi Universitas Prima Indonesia diharapkan hasil penelitian ini menjadi sumber untuk referensi peneliti lainnya yang ingin meneliti dengan jenis variabel berkaitan.

\section{DAFTAR PUSTAKA}

Atmojo, P., \& Susilowati, D. (2019). Pengaruh Struktur Modal Dan Profitabilitas Terhadap Nilai 
Perusahaan Textile Dan Garment Yang Terdaftar Di Bursa Efek Indonesia (BEI). Jurnal GeoEkonomi ISSN-Elektronik , 74.

Ayu Melyani, I. G., Suci, N. M., \& Cipta, W. (2019). Pengaruh Risiko Bisnis, Ukuran Perusahaan Dan Pertumbuhan Penjualan Terhadap Struktur Modal Pada Perusahaan Properti Dan Real Estate Yang Terdaftar Di BEI. Jurnal Prospek, vol.1 No.2.

Bhawa, I. B., \& Dewi S, R. M. (2015). Pengaruh Ukuran Perusahaan, Likuiditas, Profitabilitas, Dan Risiko Bisnis Terhadap Struktur Modal Perusahaan Farmasi. Ejurnal Managemen Unud , Vol.4 No.7.

Cahyani, N. I. (2017). Pengaruh Profitabilitas, Likuiditas, Size, kepemilikan Institutional, Dan Tangibility terhadap Struktur Modal. Jurnal Ilmu dan riset Akuntansi , 614.

Denziana, A., \& Yunggo, E. D. (2017). Pengaruh Profitabilitas, Struktur Aktiva, Dan Ukuran Perusahaan Terhadap Struktur Modal Perusahaan Pada Perusahaan Real Estate And Property Yang Terdaftar Di Bursa Efek Indonesia Tahun 2015. Jurnal Akuntansi \& Keuangan, Vol.8 No.1 Hal 51-67.

Deviani, M. Y., \& Sudjarni, L. K. (2018). Pengaruh Tingkat Pertumbuhan, Struktur Aktiva, Profitabilitas, dan Likuiditas Terhadap Struktur Modal Perusahaan Pertambangan di BEI. Manajemen Unud, 1222-1254.

Dewi, R., Suci, M., \& Mahardika, A. M. (2019). Pengaruh Profitabilitas Dan Likuiditas Terhadap Struktur Modal Perusahaan Sektor Property Dan
Real Estate Di BEI. Jurnal Prospek , vol.1 No.2.

Eviani, A. D. (2015). Pengaruh Struktur Aktiva, Pertumbuhan Penjualan, Dividend Payout Ratio, Likuiditas Dan Profitabilitas Terhadap Struktur Modal. Jurnal Akuntansi Dan Sistem Teknologi Informasi, vol. 11 No.2.

Fahmi, L. Z. (2017). Pengaruh Struktur Aktiva, Ukuran Perusahaan, Dan Likuiditas Terhadap Struktur Modal. Jurnal Ilmu dan riset akuntansi , 780.

Farisa, N. A., \& Widati, L. W. (2017). Analisa Profitabilitas, Likuiditas, Pertumbuhan Penjualan, Struktur Aktiva Dan Kebijakan Dividen Terhadap Struktur Modal. FEB Universitas Stikubank/UNISBANK, 640.

Ghozali, I. (2018). Aplikasi Analisis Multivariate Dengan Program IBM SPSS 25. Semarang: Badan Penerbit Universitas Diponegoro.

Krisnanda, P. H., \& Wiksuana, I. G. (2015). Pengaruh Ukuran Perusahaan, Pertumbuhan Penjualan, Dan Non-Debt Tax Shield Terhadap Struktur Modal Pada Perusahaan Telekomunikasi Di Bursa Efek Indonesia. E-Jurnal Manajemen Unud, Vol.4 No.5.

Kusna, I., \& Setijani, E. (2018). Analisis Pengaruh Kinerja Keuangan, Growth Opportunity Dan Ukuran Perusahaan Terhadap Struktur Modal Dan Nilai Perusahaan. Jurnal Unmer, 93-102.

Maha Dewi, D. A., \& Sudiartha, G. M. (2017). Pengaruh Profitabilitas, Ukuran Perusahaan, Dan Pertumbuhan Aset Terhadap 
Struktur Modal Dan Nilai Perusahaan. E-jurnal Manajemen Unud, vol.6 No.4.

Maryanti, E. (2016). Analisis Profitabilitas, Pertumbuhan Perusahaan, Pertumbuhan Penjualan dan Struktur Aktiva terhadap Struktur Pada Perusahaan Sektor Industri Barang Konsumsi Yang terdaftar Di Bursa Efek Indonesia. Univ Muhammadiyah Sidoarjo , 143.

Purwana, M. A., Titisari, K. H., \& Suhendro. (2019). Kinerja Keuangan, Ukuran Perusahaan Dan Struktur Modal. Univ Islam Batik Surakarta .

Qusibah, V. L., \& Yusra, I. (2019). Profitabilitas, dan Ukuran Perusahaan Sebagai Faktor Penentu Leverage Perusahaan Di Indonesia. Jurnal Pundi, vol.03 No.01.

Rahmiati, Yumna, A., \& Gusti, M. A. (2016). Analisis Pengaruh Tingkat Pertumbuhan Asset, Profitabilitas, Dan Ukuran Perusahaan Terhadap Struktur Modal. Jurnal Kajian Manajemen Bisnis, Vol. 6 No. 2.

Sari, A. N., \& Oetomo, W. H. (2016). Pengaruh Profitabilitas, Likuiditas, Pertumbuhan Aset Dan Ukuran Perusahaan Terhadap Struktur Modal. Jurnal Ilmu dan Riset manajemen, vol.5 No.4.

Seftianne. (2011). Faktor-faktor Yang Mempengaruhi Struktur Modal Pada Perusahaan Publik Sektor Manufaktur. Alumnus STIE Trisakti Jurnal Bisnis dan Akuntansi, vol. 13 No.1.

Septiani, N. P., \& Suaryana, I. G. (2018). Pengaruh Profitabilitas, Ukuran Perusahaan, Struktur Aset, Risiko
Bisnis dan Likuiditas pada Struktur Modal. E-Jurnal Akuntansi Universitas Udayana, vol.22.3.

Sugiyono. (2017). Metode Penelitian Bisnis. Bandung: Alfabeta.

Weko Hartoyo, A. K., Khafid, M., \& Agustina, L. (2014). Faktor-Faktor Yang Mempengaruh Struktur Modal Perusahaan Tekstil Dan Garmen Di BEI. Journal Unnes, AAJ 3 (2).

Widayanti, L. P., Triaryati, N., \& Abundanti, N. (2016). Pengaruh Profitabilitas, Tingkat Pertumbuhan Perusahhaan, Likuiditas, Dan Pajak Terhadap Struktur Modal Pada Sektor Pariwisata. E-Jurnal Manajemen Unud, vol.5 No.6.

Zuhro MB, F. (2016). Pengaruh Ukuran Perusahaan, Pertumbuhan Aset, Dan Profitabilitas Terhadap Struktur Modal. STIESIA Surabaya Jurnal Ilmu dan Manajemen, vol.5 No.5. 